\title{
SIELSORG AAN DIE BEJAARDE
}

\section{Dr. S. J. Prins}

Die dag van die ouderdom is nie sonder meer 'n verlengstuk van die volwasse leeftyd nie. Dit is 'n periode in die menslike lewe met sy eie aard en probleme. Gilhuis druk dit treffend uit as hy sê: „de bejaarde is niet een volwassen mens in het once', maar een mens met eigen karakterstructuur en persoonlijkheid, met speciale vragen en problemen, in velerlei opzichten verschillend van de mens die hij was op middelbare leeftijd. Hij vraagt dus een bijzondere benadering en behandeling". (C. Gilhuis, Pastorale Zorg aan Bejaarden, p. 91.)

Hieruit is dit duidelik dat die sosio-ekonomiese verbetering van die bejaarde en die blote versorging van sy liggaam nie voldoende is vir sy besondere behoeftes nie. Laasgenoemde kan kortliks opgesom word as (1) minderwaardigheidsgevoelens en die sosiale verskuiwing van sy eertydse status en rol. (2) Heimwee na die dinge wat onherroeplik verby is. (3) Skuldgevoelen; a.g.v. sy aanhoudende oordenking van werklike en gewaande tekortkomings van die verlede. (4) Bedrukte gevoelens op grond van sy lewensliefde aan die een kant en die verbysnelling daarvan aan die ander kant. ((5) Angs, wat voortvloei uit die eensaamheid waarin hy hom bevind. Die bejaarde se blik is steeds op homself gewerp en hy het altyd maar net met homself te doen.

Met nog net 'n kort stukkie van die toegemete tyd voor hom, verdwyn as 't ware sy toekoms. In 'n hede wat gevul is met al die ouderdomsgebreke en onvermoëns, sonder 'n toekoms waarin 'n doel en opdrag roep, groei die sinloosheid van die bestaan al groter. In hierdie "niks", met slegs die dood as enigste sekerheid, is die bejaarde geneig om in diepe en troostelose eensaamheid te verval.

Hier begin dan die taak van die sielsorger om teen die agtergrond van sy skrifkennis, asmede teen die agtergrond van sy kennis van die fisolofie, dog meer in besonder van die psigologie van die bejaarde, hom te ontmoet in gesprek en gebed.

\section{Die Ontmoeting :}

Die aard van die ontmoeting bepaal en beheers die verloop van die besoek. Dit behoef geen betoog dat die bejaarde met die grootste liefde, eerbied en respek benader sal word, dog nie met sentimentele neerbuigendheid nie. Die dominee moet 
die bejaarde begroet as „oom”, „meneer”, ,tante” of „mevrou”, maar onder geen omstandighede as „oumatjie”, ,oupatjie” of „oudjies”. Deur sulke aanspreekvorms word dit vir die bejaarde beklemtoon dat hy nie meer die bepaalde "persoon" is wat hy altyd was nie, maar dat hy nou ook vir die dominee net 'n ,iets"' geword het.

Die predikant moet die oues van dae liefs in sy amptelike hoedanigheid besoek. 'n Kortsluiting dreig wanneer 'n ontmoeting plaasvind tussen bejaardes wat groot geword het in 'n tyd toe daar groot waarde geheg is aan die amp van die leraar, en 'n dominee wat opgegroei het in 'n tyd toe die amp sterk gedevalueer het.

Die amptelike moet ook op die voorgrond tree t.o.v. die dominee se kleredrag in die sin dat hy deftig geklee sal wees, nie noodwendig in swart nie. Bejaardes is daar nie gewoond aan dat die leraar te sportief op sy amptelike besoeke geklee is nie. Dit kan by hulle maklik aanleiding gee tot wrewel en 'n gevolglike geringskatting van sy persoon.

Die amptelike optrede moet gedra word deur eerbied en respek vir die persoon van die grysaard - 'n eerbied en respek waarin daar ook medelye is met en 'n begrip van die swakhede van die oue dag.

Te midde van dit alles moet die dominee daarteen waak om nie in sy amptelikheid sy menslikheid te verloor nie. 'n Amptelikhoogmoedige en daarom onwaaragtige voorkoms en optrede, mag die kontakpunt in die ontmoeting onherroeplik vernietig.

\section{Die Gesprek :}

Die Bybel is die boek van ontmoetinge. Daarin staan dan ook talle voorbeelde van gesprekke opgeteken. Jesus maak van die gesprek gebruik om tot die mees intense en intieme ontmoetinge met mense te kom. Gesprekke waartydens Jesus ernstige sielewonde oopmaak, maar dit ook liefdevol verbind en toemaak. Dink maar aan die nagtelike gesprek met Nikodemus, die gesprek met die Samaritaanse vrou, en met Petrus.

Uit die aard van die saak is die pastorale gesprek, na die Woord van God, die enigste instrument in die hand van die sielsorger - ook wanneer hy die bejaardes besoek.

Hierdie gesprek is vir die bejaarde in die eensaamheid van sy oudag van onskatbare waarde. Dit word vir die bejaarde al moeiliker om die kerk te besoek. Besoek hy dit nog, verstaan 
hy dikwels nie alles in die prediking nie, omdat in dié ouderdom die gehoorskerpte afneem, die konsentrasie vermoëns verswak, en so ook die opnemingsvermoë weens die onvermoë tot verwerking van dit wat gehoor word.

Die gesprek moet rustig gevoer word. Die predikant moet stadig en duidelik praat.

Om die lewensgeskiedenis van die bejaarde te ken is baie noodsaaklik. Die verlede immers het die bejaarde betekenisvol beïnloed. Tot die verlede word gereken sy omgewing, beroep, huislike lewe, suksesse, mislukkings. As die sielsorger iets van hierdie dinge weet, sal dit hom ontsaglik baie help om sy bejaarde lidmaat te „ontmoet” in sy besondere omstandighede.

Die dominee moet probeer om iets te wete te kom van die geskiedenis van daardie tyd waarin die bejaarde geleef en ontplooi het. Kontak sal bevorder word as die dominee saam met hom in daardie tydvak kan terugleef. Hierdeur kan hy in sy psigiese vereensaming ontmoet word.

Verder moet die sielsorger oor die vermoë beskik om vol begrip en meebelewing te luister. Hier moet baie geduld aan die dag gelê word. Die bejaarde se denke en spraak is dikwels wydlopig en onsamehangend. Soms word dit tot halt geroep omdat hy name en gebeurtenisse nie kan onthou nie. Hier moet die dominee dan onopsigtelik help. Dikwels kan hy baie te wete kom uit die bejaarde se verspreiding van gedagtes. Die persoon kan daaruit geleer word.

Van baie groot belang is die kans om vrae te stel. Om kontak d.m.v. vrae te verkry, moet goed in gedagte gehou word, dat kontak eintlik uit takt bestaan. Met te veel en te vinnige vraagstelling word die grysaard verwar. Hy kry die indruk dat die dominee nie belangstel in wat hy sê, en in wat hy belangrik ag nie. Of, hy kry die indruk dat die dominee baie nuuskierig is, en dat hy meer van hom (die oumens) wil weet as wat hy graag wil of kan openbaar.

Tydens die gesprekvoering moet die predikant aandag gee aan die bejaarde se klagtes oor sy liggaam. Vir die dominee mag dit baie gering voorkom en na iepekonders lyk maar vir die bejaarde is dit baie belangrik. Belangstelling ten opsigte daarvan, sal die kontak bevorder. Vanaf die klein dingetjjies moet die sielsorger dan trag om deur te breek na die belangriker en dieperliggende klagtes.

Swygsame oomblikke in die gesprek met bejaardes is nie 
seldsaam nie. Maar sulke stil oomblikke is nooit gedagteloos nie. Die dominee moet dit aangryp en benut.

Aangesien bejaardes gou vermoei word, moet die gesprekke nie lank duur nie. Met sy geestelike toerusting, en en biddend opsien tot die Goeie Herder, moet die leraar hierdie kort gesprekke benut om die bejaarde in sy nood en eensaamheid te konfronteer met die Woord van God.

Terwyl die dominee as leraar, en as medegelowige langs die grysaard verkeer, moet hy hom wat voor die deur van die ewigheid staan ,in een bijna geëindigd heden der genade”, bedien met die troos en die tug van Gods Woord, en saam met hom kniel voor die troon van Genade.

(Word vervolg) 